\title{
Post-September 11 Discourse: The Case of Iran in The New York Times
}

\author{
Maryam Jahedi (Corresponding author) \\ Department of English, Faculty of Modern Languages and Communication \\ Universiti Putra Malaysia, 43400 UPM Serdang, Selangor, Malaysia \\ Tel: 60-13-295-1529 E-mail: jahedi_m@yahoo.com
}

Faiz Sathi Abdullah

Department of English, Faculty of Modern Languages and Communication

Universiti Putra Malaysia, 43400 UPM Serdang, Selangor, Malaysia

Tel: 60-12-978-9764Ｅ-mail: mfaiz@fbmk.upm.edu.my

Received: October 27, 2011

Accepted: December 5, 2011 Published: February 1, 2012

doi:10.5539/ijel.v2n1p59

URL: http://dx.doi.org/10.5539/ijel.v2n1p59

\begin{abstract}
This study examined how discursive strategies and related linguistic devices were employed by The New York Times (TNYT) to portray Iran after the terrorist attacks in the U.S. on September 11, 2001, and how the media representation may have contributed to negative and/or positive outcomes in terms of geopolitical relations. The study also investigated how sociopolitical assumptions were manifest in producing news about Iran and how the news discourse continued to shape the power relations between the nation and the U.S. in particular, and the world at large. Using Critical Discourse Analysis (CDA) as a multidisciplinary approach, the analysis focused on 171 front-page TNYT news articles from 2001 until 2009. Analysis of the discursive strategies and linguistic means revealed that the news media depicted an overall negative picture of Iran after the September 11 or "9/11" attacks. The effect of this rather stereotypical construction of Iran in TNYT was that of the negative Other, a nation of people that formed part of George W. Bush's contentious "axis of evil" thesis-malevolent, untrustworthy, violent, and a threat to world peace.
\end{abstract}

Keywords: Critical discourse analysis, Thematic analysis, Media representation, Post-September 11 news discourse, Iran

\section{Introduction}

The New York Times (henceforth, TNYT) is a powerful social institution that shapes news about Iran and other major geopolitical entities as well as their social representation on the global scene. After the formation of the Islamic Republic of Iran in 1979, the Western media, not least of all TNYT, has generally portrayed rather distorted and stereotyped images of Iran (Tadayon, 1982; Naficy, 1995; Keshishian, 2004). In recent years the portrayal of such negative images of Iran in almost all the international, and particularly Western, news media has been intensified as the world's major powers led by the U.S. have repeatedly expressed their apprehension about Iran, especially in relation to "Iran's nuclear program", "its influence in Iraq", and "its moral and material support for anti-Israel Islamist groups in Palestine and Lebanon" (Mafinezam \& Mehrabi, 2008, p. ix). Indeed, after the terrorist attacks of September 11, 2001, the mass media led by TNYT appears to have played a pivotal role in representing Iran as part of George W. Bush's "axis of evil" (Bush, 2002; see Peña, 2002; Heradstveit \& Bonham, 2007):

States like these, and their terrorist allies, constitute an axis of evil, arming to threaten the peace of the world. By seeking weapons of mass destruction, these regimes pose a grave and growing danger. They could provide these arms to terrorists, giving them the means to match their hatred. They could attack our allies or attempt to blackmail the United States (Bush, 2002).

There is a substantial body of research indicating the role of the U.S. media in portrayal of Iran as the negative 
Other even before 911. For instance the Islamic Revolution of Iran was represented as "the result of something more fundamental: religious reaction", and "as more the work of turbaned religious zealots" (Dorman \& Farhang, 1987, pp. 165-6). The actions of Khomeini and fellow revolutionaries of Iran were lexicalized as "crazy", "backward", "violent", and "irrational" because of their association with Islam (Gottschalk \& Greenberg, 2008). Moreover, the U.S. media portrayed Iran as a "terrorist" or "fundamentalist" country because of its "Islamic character" was seen as a threat to regional peace and the interests of the U.S. and Israel (Mughees-uddin, 1995; Richardson, 2004, Salim, 2010). Such negative images of Iran intensified following the September 11 attacks when President George W. Bush framed Iran as part of the "axis of evil" together with Iraq and North Korea (Peña, 2002; Heradstveit \& Bonham, 2007).

As the coverage of international events in the U.S. media, especially $T N Y T$, generally conforms to the foreign policy of the U.S. government, which has a history of turbulent relations with the Middle East state (Fishman, 1980; Bennet, 1993; Carpenter, 1995), it is important to illustrate how representations of Iran as a nation in the language of the U.S. news media may serve to meet certain interests. Further, it is necessary to examine how the U.S. media in general and TNYT in particular, in portraying Iran as being at odds with U.S. interests, may manufacture readers' consent discursively (Herman \& Chomsky, 2002).

Indeed, previous studies show that dominant mass media play a significant role in marginalizing the Other, as argued by Herman and Chomsky (2002) who add that the U.S. media in particular tends to misrepresent the events happening in the world and marginalize dissent so as to allow the dominant interests to get their messages across to the public. In the case of Iran, Izadi and Saghaye-Biria (2007) point to how editorials of the elite American newspapers TNYT, The Washington Post, and The Wall Street Journal, cover the Iranian nuclear program in negative terms by appropriating Orientalism "as a 'discoursive conception of the Orient ... [that] involves a binary opposition that finds the West as central in modern, enlightened thought, and the Orient as the mysterious and often dangerous Other" Hartley, 2002, p. 170, cited in Izadi \& Saghaye-Biria, 2007, p. 140). In analyzing the editorials of these newspapers, the authors reason, after Henry and Tator (2002), that "Unlike news discourse, editorials are conversations among a society's economic and power elites, with the public being less of an addressee than spectators". However, a case may also be made for the critical analysis of more "homely" media discourse such as online news abstracts to which everybody has access and is therefore shaped by them (Van Dijk, 2002).

Hence, the present study was an attempt to complement, and thereby extend, the findings of past studies on Iran by analyzing the role of language use in the discursive representation of the Iranian nation via news abstracts to uncover the linguistic means and/or text structures that serve as cues to discursive strategies, topics, issues, and themes of contention as well as the underlying ideologies. The following research questions were addressed:

RQ1: What are the topics and themes that are recurrent and emphasized in TNYT news articles about Iran since the $9 / 11$ attacks?

RQ2: What discursive strategies and associated linguistic means or forms are employed in the realization of the strategies to construct Iran in the news media?

RQ3: What ideologies about Iran seem to underlie its discursive representation and how do these serve to maintain the status quo?

\section{Theoretical Framework}

Critical discourse analysis analyzes language as discourse, which means that "language is conceived as one element of the social process dialectically interconnected with others" (Fairclough \& Graham, 2002, p. 188). The study drew on a combination of analytical tools and approaches advocated by prominent scholars in the field such as Fairclough (1993, 1995, 2001); Wodak (Fairclough \& Wodak, 1997; Wodak, 2001; Reisigl \& Wodak, 2001); and Van Dijk (1984, 1991, 2001a, 2001b). Fairclough's (2001) socio-critical approach focuses on discourse (language) as a form of social practice. Fairclough's (ibid.) framework of discourse is distinguished by three levels of meaning: 1) text, which can refer to both spoken and written language; 2) interaction, which means the process of text production and text interpretation; and 3) context, which refers to broader social and cultural conditions. Corresponding to these three dimensions of discourse, he (2001) postulates three dimensions of analysis: description, interpretation, and explanation.

The stage of description focuses both on the forms and meanings of a text (Fairclough, 2001, 1995). Fairclough (1995) believes that it is difficult to separate these two features of the texts, for the reason that "meanings are necessarily realized in forms and differences in meaning entail differences in form" (p. 57). Linguistic analysis of a text covers traditional forms of linguistic analysis (such as vocabulary, semantics, grammar, phonology, and 
writing system analyses), but includes textual organization above the sentence (such as cohesion and turn taking) which relates to Halliday's (1994) Systemic Functional Linguistics (SFL) (Fairclough, 1995). For text analysis, Halliday's (1994) systemic model of language is suggested because it "is profoundly concerned with the relationship between language and other elements and aspects of social life, and its approach to the linguistic analysis of texts is always oriented to the social character of texts" (Fairclough, 2003, p. 5). The stage of interpretation mediates between text and social practice. It involves the process of text production, as well as the process of text interpretation/consumption (Fairclough, 2003). Interpretation is concerned with the cognitive processes of participants in text production and text interpretation (Fairclough, 2001, 2003). Finally, the stage of explanation is concerned with analysis of the relationship between interaction as well as social context of production and interpretation (Fairclough, 2001). It is related to different levels of abstraction from an event: immediate situational context, institutional practices the event is embedded within, and the society (Fairclough, 1995, 2001).

Wodak's discourse-historical approach is fundamentally compatible with Fairclough's approach to critical analysis of discourse in a way that both consider discourse as a form of social practice (Fairclough \& Wodak, 1997). Wodak's (2001) discourse-analytical approach is also somewhat three-dimensional: contents or topics, discursive strategies, and linguistic means. In her work, first she (ibid.) identifies the specific contents or topics of a specific discourse with racist, nationalist and/or ethnicist ingredients before examining discursive strategies and the linguistic means as well as the specific, context-dependent textual features of discriminatory stereotypes (Wodak, 2001).

Wodak (2006) proposes four macro strategies of discourse in the analysis of national identities in relation to sociological macro functions: 1) constructive strategies that "serve to construct national identities"; 2) perpetuating strategies which "may restore or justify certain social status quo"; 3) transformational strategies "instrumental in perpetuating and producing the status quo"; and 4) destructive strategies concerning "discursive practices may have an effect on the transformation or even destruction of the status quo" (p.112). In analyzing texts related to races, ethnicities, nations, or national identities, Wodak's postulation of these discursive strategies orients towards five questions:

1) How are persons named and referred to linguistically? (referential strategies).

2) What traits, characteristics, qualities and features are attributed to them? (predicational strategies).

3) By means of what arguments and argumentation schemes do specific persons or social groups try to justify and legitimate the exclusion, discrimination, suppression, and exploitation of others? (argumentation strategies, including fallacies).

4) From what perspective or points of view are these namings, attributions and arguments expressed? (perspectivation, and framing strategies).

5) Are the respective discriminating utterances articulated overtly, are they even intensified or are they mitigated? (mitigation and intensification strategies) (Reisigl \& Wodak, 2001, p. xiii).

Further, Wodak's approach additionally links with Van Dijk's (1984, 1991, 2001a, 2001b) socio-cognitive theory of discourse as a form of knowledge and memory (Reisigl \& Wodak, 2001). With Van Dijk's attention to the representation of groups and the social relations between them, his approach is useful for analysis of news discourse to examine the socio-ideological representation of Us versus Them. Van Dijk's (2001a) starts with an analysis of topics (semantic macrostructures or global meanings) which he argues gives "a first, overall, idea of what a discourse or corpus of texts is all about, and controls many other aspects of discourse and its analysis" (p. 102). Next, he focuses on the analysis of local (micro structures) meanings, such as "the meaning of words (lexical), the structures of propositions, and coherence and other relations between propositions" (p.103). Then, both at the level of global and local meaning analysis, he recognizes "an overall strategy of "positive self-presentation and negative other presentation', in which our good things and their bad things are emphasized, and our bad things and their good things are de-emphasized" (p.103).

\section{Method}

The data that were analyzed in the present study included news articles of The New York Times (TNYT) focusing on events in Iran after the terrorist attacks of September 11, 2001. To gather the data, the archives of TNYT were accessed for news texts about Iran since 2001 till 2009 (http://www.nytimes.com/ref/membercenter/nytarchive.html). Using "Iran" as the search term, 171 front-page news articles about Iran were obtained which were then copied and pasted to files in Microsoft Word format. The study concentrated on headlines and the lead paragraphs of the front-page news articles because they summarize 
the whole content of the news articles, and they have significant textual and cognitive functions; therefore, they deserve particular attention (Van Dijk, 1991; Smith, 1999). Moreover, headlines often have ideological implications in that they give a subjective definition of the situation and have a powerful influence on the interpretation of a news report (Van Dijk, 1991).

The headlines and the corresponding lead paragraphs in the corpus were examined to discern what issues/topics, and major themes were selected and emphasized by $T N Y T$, what ideological implications there were due to recurrence of those topics or themes, as well as what discursive and linguistic means of their realization were employed to construct ideological representations of events in relation to Iran.

\section{Results and Discussion}

\subsection{Thematic analysis}

This step in the present critical analysis was concerned with a careful examination of TNYT news abstracts to identify the themes, or semantic macro-structures defining "what speakers think or discursively display as the most important information or opinions about Us and Them" (Van Dijk, 2000b, p. 90). Therefore, to reveal the assumptions about the Iranian nation in the news discourse, the focus was on themes or topics to see what was presented as most salient in the news texts. The major themes that emerged in the analysis of the selected news texts since 2001 till 2009 are presented below:

\subsubsection{Iran's sponsorship of terrorism}

The theme of Iran as a sponsor of terrorism appeared to be made explicit through the following topics: Iran as the supporter of terrorist bombing at the Khobar Towers; Iran as an ally of Osama bin Laden; Iran's involvement in the bombing of a Jewish community center; ties between the Iranian government and the terrorist group involved in the September 11 attacks; and, labeling Iran Guards as terrorists. Examples are given below with crucial, incriminating lexicalizations and/or wordings in bold:

1). 14 Incited by U.S. in '96 Saudi blast; Iran link is cited (June 22, 2001).

2). A federal grand jury returned a 46-count indictment today charging 13 Saudis and a Lebanese man, who officials said were supported by Iran, with a truck bombing at the Khobar Towers apartment building in Saudi Arabia that killed 19 American airmen and wounded nearly 400 others in 1996 (June 22, 2001).

3). Bin Laden sought Iran as an ally, U.S. intelligence documents say (December 31, 2001).

4). Representatives of Osama bin Laden contacted Iranian intelligence agents in the mid-1990's in an attempt to forge an anti-American alliance of terror between Iran and Mr. bin Laden's network, Al Qaeda (December 31, 2001).

5). Iran blew up Jewish center in Argentina (July 22, 2002).

6). The Iranian government organized and carried out the bombing of a Jewish community center here eight years ago that killed 85 people ... (July 22, 2002).

7). President says U.S. to examine Iran-Qaeda tie (July 20, 2004).

8). President Bush said on Monday that the United States was actively investigating ties between the Iranian government and Al Qaeda, including intelligence unearthed by the independent Sept. 11 commission showing that Iran may have offered safe passage to terrorists who were later involved in the attacks (July 20, 2004).

9). U.S. Is weighing terrorist label for Iran Guards (August 15, 2007).

10). The Bush administration is preparing to declare that Iran's Revolutionary Guard Corps is a foreign terrorist organization, senior administration officials said Tuesday (August 15, 2007).

Representing Iran as the active agent of negative actions clearly served to paint a negative picture of Iran as a terrorist state and/or a terrorist ally, which the following clauses show: "Iran blew up Jewish center in Argentina"; and "the Iranian government organized and carried out the bombing of a Jewish community center". Moreover, through the strategy of relationalization (Reisigl \& Wodak, 2009) which is realized in words such as "ally" and "alliance", an attempt was to show up the alleged relationship between Iran and bin Laden's network which directly linked Iran to the terrorist group in question. Constructing Iran as the sponsor of terrorism was, of course, also intensified by labeling Iran's Revolutionary Guards as "terrorists".

It is interesting to note that during Khatami’s presidency, the news media categorized Khatami, the president, and 
his supporters as "good" and labeled them as "reformists", "reformers", and "pro-democracy" (See Richardson, 2004). This theme of support for Iran was further seen as being in line with the Clinton Administration's policy that offered "gestures of support for Iran" (TNYT, March 26, 1998). The then Secretary of State, Madeleine K. Albright, also "declared a commitment to take extensive steps toward ending two decades of hostility" (NYT, March 18, 2000). However, after George W. Bush's rise to power in 2001, Iran was categorically alleged as a major sponsor of terrorism.

\subsubsection{Threat of nuclear weapons}

The theme of Iran's nuclear threat was seen in the following topics: the U.S. concern over Iran's pursuit of nuclear program; seeking international support for increasing pressure on Iran; regarding Iran along with North Korea as major threats; and concern about Iran's plan in producing nuclear arms.

1). New U.S. concerns on Iran's pursuit of nuclear arms (May 8, 2003).

2). President Bush ... spent the day trying to increase pressure on two other nations he regards as major threats -- Iran and North Korea -- to give up their nuclear weapons programs (June 2, 2003).

3). Iran is said to have new nuclear plans (June 7, 2003).

4). A report from the International Atomic Energy Agency says Iran is planning nuclear facilities that could give it new options for producing nuclear arms (June 7, 2003).

5). Bush says U.S. will not tolerate building of nuclear arms by Iran (June 19, 2003).

6). President Bush said for the first time today that the United States and its allies "will not tolerate the construction of a nuclear weapon" in Iran ... (June 19, 2003).

7). Atomic activity resumes in Iran amid warnings (August 9, 2005).

By the use of words such as "concern", "threat", and "atomic activity" to refer to Iran's nuclear program above, TNYT represented Iran as a threat; indeed, it was labeled a "major threat" to (re)produce in the undiscerning reader the conclusion that Iran's intention was to obtain/produce nuclear weapons. Moreover, the statement attributed to President Bush in the following clause ("the United States and its allies 'will not tolerate the construction of a nuclear weapon"') presupposed the idea that Iran aimed to construct nuclear weapons. Besides, putting "atomic activity" in thematic position reinforced the idea that Iran's nuclear program was indeed a threat. Therefore, although it was not proven conclusively that Iran aimed to make nuclear weapons (see Izadi \& Saghaye-Biria, 2007), attempts were made to portray Iran as a nuclear threat.

4.1.3 Iran's involvement in the Iraq war

Iran's involvement in the Iraq war was identified by mediatized topics such as Iran's support of Shiite insurgents in Iraq; threatening the security of American troops in Iraq; supplying Shiite militants in Iraq with bombs that killed American troops; supporting Islamic militants who killed American soldiers.

1). Deadliest bomb in Iraq is made by Iran, U.S. says (February 10, 2007).

2). The most lethal weapon directed against American troops in Iraq is an explosive-packed cylinder that United States intelligence asserts is being supplied by Iran (February 10, 2007).

3). Bush declares Iran's arms role in Iraq is certain (February 15, 2007).

4). President Bush said Wednesday that he was certain that factions within the Iranian government had supplied Shiite militants in Iraq with deadly roadside bombs that had killed American troops (February 15, 2007).

5). U.S. says raid in Iraq supports claim on Iran (February 26, 2007).

6). U.S. says Iran helped Iraqis kill five G.I.'s (July 3, 2007).

7). Agents of Iran helped plan a January raid in Shiite holy city of Karbala in Iraq in which five American soldiers were killed by Islamic militants, an American military spokesman said Monday. The charge was the most specific allegation of Iranian involvement in an attack that killed American troops, at a time of rising tensions with Iran over its role in Iraq and its nuclear program (July 3, 2007).

8). U.S. says Iran-supplied bomb kills more troops (August 8, 2007).

9). Attacks on American-led forces using a lethal type of roadside bomb said to be supplied by Iran reached a new high in July, according to the American military (August 8, 2007).

10). The United States has gathered its most detailed evidence so far of Iranian involvement in training 
and arming fighters in Iraq, officials say, but significant uncertainties remain about the extent of that involvement and the threat it poses to American and Iraqi forces (April 26, 2008).

It the above examples, verbal processes (Halliday, 1994) realized in verbs such as "say" and "declare" were frequently used to represent the U.S. view on Iran's involvement in the Iraq war of 2003 (Mafinezam \& Mehrabi, 2008) as the following clauses illustrate: "Bush declares Iran's arms role in Iraq is certain"; "U.S. says Iran helped Iraqis kill five G.I.'s". Representing Iran as the supplier of the weapons and bombs to Iraqis who killed American soldiers intensified Iran's role in the Iraq war. Further, labeling Iraqis as "Shiite militants", and "Islamic militants" contributed to a negative picture of Muslims and Islam (Richardson, 2004; Salim, 2010), and describing Iran as the "supporter" of those militants emphasized the supposed role of Iran in the Iraq war. However, the role of the U.S. in the invasion of Iraq which was allegedly based upon a vast error of judgment was not highlighted (Fox, 2009).

4.1.4 The need for action to eliminate the nuclear threat

The following topics show the need for supposedly viable actions to eliminate the threat: negotiating with Iran over its nuclear program; to step up pressure on Iran to give up all elements of its nuclear program; persuading Iran to extend freeze in nuclear work; proposing European shield for Iran missiles; and, proposing sanctions on Iran including restrictions on imports of nuclear-related equipment and material.

1). Europe and the United States have agreed on a joint approach to negotiating with Iran over its nuclear program ... (March 11, 2005).

2). Sharon asks U.S. to pressure Iran to give up its nuclear program (April 13, 2005).

3). Europe gets Iran to extend freeze in nuclear work (May 26, 2005).

4). The foreign ministers of Britain, France and Germany persuaded Iran on Wednesday to continue its freeze on nuclear activities, averting a diplomatic crisis that could have led to punitive international measures against Iran (May 26, 2005).

5). Europe joins U.S. in urging action by U.N. on Iran (January 13, 2006).

6). U.S. is proposing European shield for Iran missiles (May 22, 2006).

7). The Bush administration is moving to establish a new antimissile site in Europe that would be designed to stop attacks by Iran against the United States and its European allies (May 22, 2006).

8). U.S. drafting sanctions as Iran ignores deadline (August 31, 2006).

9). With Iran defying a Thursday deadline to halt production of nuclear fuel, the United States and three European allies are assembling a list of sanctions they would seek in the United Nations Security Council, beginning with restrictions on imports of nuclear-related equipment and material (August $31,2006)$.

Some words used in the examples above emphasized the actions against Iran to stop its nuclear activities such as "pressure", "sanctions", "freeze", "restrictions", etc. Through material processes (Halliday, 1994), the U.S. participants were represented as the social actors who emphasized actions to remove the threat caused by Iran. For example, the U.S. role was highlighted as the actor who tried to "establish antimissile sites in Europe", and to "draft sanctions" to stop attacks by Iran.

From 2005 onward, after Ahmadinejad had won the presidential election, it would seem that the threat from Iran had intensified. The U.S. Secretary of State, Condoleezza Rice, declared that "the U.S. faces no greater challenge from a single country than from Iran" (Rice, 2006). However, the media opposed Iran's right to produce nuclear energy (Izadi \& Saghaye-Biria, 2007) despite Ahmadinejad's (2009) argument that "nuclear energy, if it is good, it should be for all. And if it is bad, nobody should use that technology".

\subsubsection{Internal unrest}

Internal unrest in Iran was highlighted in TNYT by emphasizing the people's disagreement with their president on his nuclear strategy; opposition of students to president Mahmoud Ahmadinejad; highlighting people's protest against the president; and, underlining government crackdown on people including labor leaders, universities, the press, women's rights advocates, etc.

1). In Iran, dissenting voices rise on its Leaders' nuclear strategy (March 15, 2006).

2). Just weeks ago, the Iranian government's combative approach toward building a nuclear program produced rare public displays of unity here. (March 15, 2006).

3). Iran president facing revival of students' ire (December 21, 2006). 
4). As protests broke out last week at a prestigious university here, cutting short a speech by President Mahmoud Ahmadinejad, Babak Zamanian could only watch from afar. (December 21, 2006).

5). Rebuke in Iran to its president on nuclear role (January 19, 2007).

6). Iran's outspoken president, Mahmoud Ahmadinejad, appears to be under pressure from the highest authorities in Iran to end his involvement in its nuclear program, a sign that his political capital is declining as his country comes under increasing international pressure (January 19, 2007).

7). Iran cracks down on dissent, parading examples in streets (June 24, 2007).

In the above news excerpts, lexical words such as "dissent", "ire", "rebuke", and so on were used to emphasize the Iranians' disagreement with their president, Ahmadinejad, on the state's nuclear program.

\subsubsection{Post-electoral unrest}

Post-electoral unrest in Iran was represented by the following topics: highlighting violence over Iran's disputed presidential election; emphasizing demonstrations against the election results; highlighting people's demonstration in defiance of the Islamic government; giving emphasis to the rift between Iran's political elite and clerical establishment over the election crisis; and, emphasizing people's defiance against the country's supreme leader; and the government's attempt to suppress the opposition group.

1). The streets of Iran's capital erupted in the most intense protests in a decade on Saturday, with riot police officers using batons and tear gas against opposition demonstrators who claimed that President Mahmoud Ahmadinejad had stolen the presidential election (June 13, 2009).

2). Unrest deepens as critics are detained (June 14, 2009).

3). Violence and acrimony over Iran's disputed election intensified on Sunday, with word spreading that more than 100 prominent opposition members had been detained, riots erupting in Tehran and other cities, and the triumphant incumbent hinting that his top challenger risks punishment for questioning the result (June 14, 2009).

4). Iran's leaders failed on Tuesday to halt a second day of huge demonstrations against last week's election results but, placed on the defensive, offered another concession to the sustained rage here, saying they would allow a limited recount (June 16, 2009).

5). As another day of defiance, concessions and ominous threats transfixed Iran's capital, it was increasingly apparent on Thursday that there was no clear path out of a deepening confrontation that has posed the most serious challenge to the Islamic republic in its 30 -year history (June 18, 2009).

6). Unrest in Iran sharply deepens rift among clerics (June 21, 2009).

7). Clerical leaders defy Ayatollah on Iran election (July 4, 2009).

8). An important group of religious leaders in Iran called the disputed presidential election and the new government illegitimate on Saturday, an act of defiance against the country's supreme leader and the most public sign of a major split in the country's clerical establishment (July 4, 2009).

9). As Iran's political elite and clerical establishment splinter over the election crisis, the nation's most powerful economic, social and political institution - the Islamic Revolutionary Guards Corps - has emerged as a driving force behind efforts to crush a still-defiant opposition movement (July 20, 2009).

Words and phrases in TNYT headlines and leads such as "protest", "unrest", "violence", "acrimony", "confrontation", "disputed presidential election", and "election crisis" emphasized the unrest in Iran after the presidential contest between Mahmoud Amadinejad and Mir Hossein Mousavi in 2009. TNYT tried to highlight the "fact" that the relationship between Iran's supreme leader, Khahmenei, and the Iranian people was shaken. It is argued that using lexical items such as "intense", "huge", and "deep confrontation" to describe the demonstration against the government, was an attempt to emphasize that large numbers of people in Iran did not agree with the Islamic government, and thus to promote the idea that the Iranian people wanted regime change.

\subsubsection{Threat of nuclear bombs}

Threat of nuclear bombs was thematized in TNYT in terms of the fear of Iran's access to nuclear weapons and concern over Iran's assumed development in the making of nuclear bombs.

1). Clinton speaks of shielding Mideast from Iran (July 22, 2009).

2). Stiffening the American line against Iran, Secretary of State Hillary Rodham Clinton warned 
Wednesday that the United States would consider extending a "defense umbrella" over the Middle East if the country continued to defy international demands that it halt work that could lead to nuclear weapons (July 22, 2009).

3). U.S. says Iran could expedite nuclear bomb (September 9, 2009).

4). American intelligence agencies have concluded in recent months that Iran has created enough nuclear fuel to make a rapid, if risky, sprint for a nuclear weapon. (September 9, 2009).

5). U.S. and allies warn Iran over nuclear 'deception' (September 25, 2009).

6). Report says Iran has data to make a nuclear bomb (October 3, 2009).7). Senior staff members of the United Nations nuclear agency have concluded in a confidential analysis that Iran has acquired "sufficient information to be able to design and produce a workable" atom bomb (October 3, 2009).

Words such as "nuclear weapon", "nuclear bomb", and "atom bomb" were frequently used to underline Iran's intention to acquire nuclear bombs. Moreover, the statements, "shielding Mideast from Iran" and "extending a 'defense umbrella' over the Middle East" represented Iran as threatening social entity against which any action would be justified. Besides, the verbal process (Halliday, 1994) realized in verbs such as "warn" was repeatedly used by the U.S. "sayers" to emphasize the concern over Iran-dominated nuclear issues (Mafinezam \& Mehrabi, 2008). It may be noted here that the analysis suggests that constructing Iran as a nuclear threat has also continued during the Obama administration.

Even a cursory survey of the major themes that emerged in the current study would reveal that the mainstream U.S. news media in question here tried to depict a negative picture of Iran following the September 11 attacks when President George W. Bush labeled Iran as part of the "axis of evil". As Sullivan (2002) succinctly summarizes the following U.S. perceptions of Iran:

September 11, 2001 is seared into the minds of many Americans as 911. If you mention this number to anyone in the US they will think of the World Trade Towers and the Pentagon attacks, and the 3,000 persons who were murdered that day. ...Many Americans do not have good feelings about Iran. The press has not helped (Sullivan, 2002, p. 178).

Indeed, the role of the U.S. press in particular has done little to assuage American fears; on the contrary, it probably served to (re)produce those very fears in the construction of Iran as the evil, recalcitrant Other.

\subsection{Analysis of linguistic means and discursive strategies}

A closer look at topics and themes revealed that words were chosen to represent Iran ideologically as the negative Other. As Van Dijk (1995) states, "the major dimension of discourse meaning controlled by ideologies is the selection of word meaning through lexicalization" (p. 259). Therefore, by focusing on the ways the Iranians were lexicalized in the headlines and leads of TNYT front-page news articles, the study showed that lexical items were consistently used to denote concepts which serve particular ideological purposes:

1) Words indicating a problematic situation, such as violence, crisis, strife, upheaval, turmoil, chaos, riot, splintered, insurrection, etc.

2) Words describing extremism, such as extremist, terrorism, militants, hard-liners, Islamists, radical, bigot, etc.

3) Words referring to threat, such as terror, violent, insurrection, militants, ferocious, terrorist, axis of evil, etc.

4) Words denoting religious association, such as Islamic militants, hard-line Moslems, etc.

Attaching negative attributes to the Iranian social actors through the use of a predicational strategy quite obviously played an important role in the construction of Iranian identity in TNYT news articles after September 11,2001 . It was seen that negative words were assigned to the Iranian participants to construct them as violent people, militants, supporters of terrorism, among other equally negative attributes. Moreover, there was a tendency to explain the act of violence and terrorism with references to the religion of Islam such as Islamic militants, Islamic terrorist, Islamic radicals, etc. (Richardson, 2004; Izadi \& Saghaye-Biria, 2007) in a chain of equivalence. By association of religious aspects of the Iranian people with the negative words such as violence, terrorism, fundamentalism, etc. Islam was represented as a religion which had an influence in those inhuman acts. Besides, employing lexical items such as "threat", "axis of evil", "terrorists", and so on probably had an ideological effect on the reader of the media. This included the naturalized representation of Iran as a threat which lends itself to the logical assumption that something needed to be done to remove the threat.

The present analysis also suggests that $T N Y T$ generally aimed to assign negative attributes to the Iranian nation 
as a whole to allow the reader to think that the negative traits and characteristics were features of not only the Iranian government, but also the Iranian people (see Peña, 2002). It can be argued that the choice of lexical items contributed to the demonization of Iranian participants and to discredit them, which thereby show how the situated discourse may serve the representation of Iran as the negative Other.

To legitimize the construction of such a negative image of Iran and to justify the notion that the West had to unite to fight against it, different argumentation strategies (Reisigl \& Wodak, 2001, pp. 71-79) were used. The strategy of argumentum ad baculum was probably used the most to threaten and intimidate Iran in the news discourse. By constructing the state as a threat to national and global security, the U.S. itself threatened and warned Iran of impending sanctions, for instance, and called on its allies to join the pre-emptive actions against Iran. For example, the U.S. repeatedly warned Iran that it would suffer consequences if it would not stop destabilizing the government of Afghanistan:

President Bush warned Iran today that it must not try to undermine the new interim government of Afghanistan, or it will face consequences from the same American-backed coalition that ousted the Taliban from power (January 11, 2002).

The topos of danger or threat may be discerned in the TNYT discourse with the implication that as Iran was considered a threat, one should do something to eliminate the threat. By referring to the U.S. claim that Iran helps terrorists, and presenting the putative support for that claim by other nations, news headlines and lead stories represented Iran as a dangerous country, and thus to justify U.S. actions against Iran. For instance, with the claim that Iran was a sponsor of terrorism and a major threat to world peace, TNYT apparently legitimized U.S. pressure on Iran to give up its nuclear program, and the imposing of sanctions.

1) President Bush ... spent the day trying to increase pressure on two other nations he regards as major threats -- Iran and North Korea -- to give up their nuclear weapons programs (June 2, 2003).

2) The Bush administration will announce a long-debated policy of new sanctions against Iran on Thursday, accusing the elite Quds division of the Revolutionary Guard Corps of supporting terrorism, administration officials said Wednesday night (October 25, 2007).

Representing Iran as a dangerous country that intends to produce nuclear bombs to launch an attack "against the United States and its European allies", rather than as a country which intends to develop nuclear energy for peaceful purposes probably gave reason for "proposing European shield for Iran missiles". The Unites States' role in urging, ordering, and pressing other nations to consent to the idea of isolating Iran was therefore justified through this negative construction of Iran in its mainstream media:

1) U.S. Is Proposing European Shield for Iran Missiles (May 22, 2006).

2) The Bush administration is moving to establish a new antimissile site in Europe that would be designed to stop attacks by Iran against the United States and its European allies (May 22, 2006).

Moreover, the topos of authority was used to represent the U.S. and its allies as the authorities that took charge of world affairs. For example, taking actions against Iran appeared to be legitimized by TNYT because the U.S. as a powerful nation wanted it. Perhaps Western allies of the U.S. such as Britain promised to support the U.S. against Iran and also agreed to impose sanctions on Iran just because the U.S. as a powerful country had perceived a dire need to act. Referring to the U.S. allies as the authorities that supported the U.S. actions against Iran implied that the U.S. perception was true because other powerful nations said so (Van Dijk, 2000c). Hence, the legitimation of U.S. actions could be seen through the claimed consensus that had been achieved among the Western countries.

1) Europe and the United States have agreed on a joint approach to negotiating with Iran over its nuclear program ... (March 11, 2005).

2) The foreign ministers of Britain, France and Germany persuaded Iran on Wednesday to continue its freeze on nuclear activities, averting a diplomatic crisis that could have led to punitive international measures against Iran (May 26, 2005).

3) Europe joins U.S. in urging action by U.N. on Iran (January 13, 2006).

4) With Iran defying a Thursday deadline to halt production of nuclear fuel, the United States and three European allies are assembling a list of sanctions they would seek in the United Nations Security Council, beginning with restrictions on imports of nuclear-related equipment and material (August 31, 2006). 


\subsection{Ideologies}

The analysis of various recurring themes revealed the ideology of excluding or "outcasting" (Lazar \& Lazar, 2004) Iran's Islamic state based on the assumption that it was obsessed by the ideas of violence, fundamentalism, and extremism (see Richardson, 2004; Salim, 2010). The overarching idea in TNYT that Iran (the entire country) was to be seen as a threat became dominant in the news discourse to naturalize this ideology and thereby to win world acceptance for isolating Iran and imposing sanctions. Furthermore, the negative portrayal of the Iranian state and its participants and positive representation of the U.S. served to create a bipolar set of power relations which constructed the superiority of the U.S. and the inferiority of the Iranian Other.

The political power structure of the U.S. vis-à-vis Iran was reflected in the data in various ways. Political ideology had an influence on representation of Iran in the news discourse as The NYT adjusted its content according to U.S. policy on Iran as it obviously supported U.S. views. What was probably patent on the part of the TNYT was that it tried to create an unbalanced and biased discourse which promoted the point of views of the U.S. (Salim, 2010). Generally, there was a tendency to legitimize and encourage policies and views of the U.S. and to highlight conditions unfavorable to the Iranian actors. For example, it was not proven that "North Korea, Iran, or Iraq have any linkages to or have provided support or safe haven to al Qaeda. And none have been shown to be complicit in the planning, financing, or conduct of the September 11 attacks" (Peña, 2002, p. 7). However, Iran was portrayed as a major threat "because the United States continues to believe in the myth of a military requirement to ensure the flow of cheap oil from the Persian Gulf" (ibid., p. 8). The attempt to represent Iran as a sponsor of terrorism, its ties with Osama bin Laden who was responsible for the $9 / 11$ terrorist attacks, and to highlight its aim to acquire nuclear bombs implied Iran's responsibility not only for the $9 / 11$ attacks, but also for any other terrorist attacks that happened or might have happened.

The representation of the Iranian nation in TNYT news articles helped reproduce the existing discourse of representing Muslims as negative (Richardson, 2004). This was realized through the negative themes and topics about Iranian actors, representing their actions as violent, and assigning negative attributes and characteristics to them. It also helped reproduce Muslims as a threat that needed to be dealt with. The Iranian nation was portrayed as Muslim people who were violent, militants, aggressive, fundamentalists, terrorists, etc. which implied that they were backward and against democracy. Therefore, this kind of representation reinforced the existing perceptions that Muslims were a threat to national/global security and the U.S. as a superpower had the right to act against them. As a result, the portrayal of the Iranian nation supported the dichotomy of Us versus Them where Us represented the U.S. and its allies, but Them represented the Iranian nation and its people.

\section{Conclusion}

The analysis of the news discourse of TNYT following the 9/11 attacks revealed that the major themes which dominated TNYT news discourse about Iran emphasized the concepts of violence, threat, etc., and highlighted the negative representation of Iran. Furthermore, by using negative lexical items, Iranian social actors were represented in such a stereotypical way that they were associated with fundamentalism, violence, and threat. The study showed that words or expressions with which the news articles discursively constructed the Iranian nation were chosen to categorize the U.S. and its allies (e.g., Europe) as the in-group and Iran (the entire country) as the out-group.

Representing the Iranian social actors in different contexts by TNYT as supporters of terrorism with the threat of nuclear arms contributed to discrimination against the Iranian nation and justification for the actions towards isolating it. The net effect of the discourse themes, strategies and associated linguistic means of realization in the stereotypical construction of Iran in TNYT would be that of the negative Other, a nation of people that formed part of George W. Bush's contentious "axis of evil" thesis - malevolent, untrustworthy, violent, and a threat to world peace despite the subsequent U.S. administration efforts at positive engagement for some semblance of normalcy in bilateral relations.

It can be concluded that not only social contexts may determine the way news discourses are produced, but also that discourses which contribute to sustaining social power in turn constitute the same contexts. On the one hand, the impact of social events such as the September 11 attacks seemed to determine and structure the news discourse about Iran, and on the other hand, the nature and role of the discourse itself was crucial in the ideological representation of the event in question and the events that followed, thereby perpetuating the existing social power relations and the status quo. It is hoped that the current study contributes towards an increasing awareness of how mainstream news media may construct a particular representation and skew related reader perceptions about an entire nation through the appropriation of language as discourse. 


\section{References}

Ahmadinejad M. (2009). Iran Ready for Nuclear Dialogue: Ahmadinejad. Geneva (Reuters). [Online] Available: http//www.Reuters.com/article/2009/04/20/us-iran-nuclear-sb-idUSTRE53J4FW20090420 (April 20, 2009)

Bennet, W. L. (1993). Constructing Publics and Their Opinions. Political Communication, 10, 101-20. http://dx.doi.org/10.1080/10584609.1993.9962970

Bush, G. W. (2002). Bush State of the Union Address. CNN. [Online] Available: http://edition.cnn.com/2002/ALLPOLITICS/01/29/bush.speech.txt/ (January 29, 2002)

Carpenter, T. G. (1995). The Captive Press: Foreign Policy Crisis and the First Amendment. Washington: Cato Institute.

Dorman, W. A. \& Farhang, M. (1987). The U.S. Press and Iran: Foreign Policy and the Journalism of Difference. Berkeley: University of the California Press.

Fairclough, N. \& P. Graham. (2002). Marx as Critical Discourse Analyst: the Genesis of a Critical Method and its Relevance to the Critique of Global Capital. Estdios de Sociolinguistica, 3(1), 185-229.

Fairclough, N. (1993). Discourse and Social Change. USA: Blackwell.

Fairclough, N. (1995). Media Discourse. London: Edward Arnold.

Fairclough, N. (2001). Language and Power. London: Longman.

Fairclough, N. (2003). Analysing Discourse: Textual Analysis for Social Research. New York: Routledge.

Fairclough, N. L. \& Wodak, R. (1997). Critical Discourse Analysis. In T.A. Van Dijk (Ed.), Discourse as Social Interaction: Discourse Studies 2 (A Multidisciplinary Introduction) (pp. 258-284). London: Sage.

Fishman, M. (1980). Manufacturing the News. Austin: University of Texas Press.

Fox, S. (2009). Fragmentz. England: Growly Bear Books.

Gottschalk, P. \& Greenberg, G. (2008). Islamophobia: Making Muslims the Enemy. USA: Rawman \& Littlefield.

Halliday, M .A. K. (1994). An Introduction to Functional Grammar (2 nd ed.). London: Arnold.

Henry, F. \& Tator, C. (2002). Discourses of Domination: Racial Bias in the Canadian English language Press. Toronto: University of Toronto Press.

Heradstveit, D. \& Bonham, G., M. (2007). What the Axis of Evil Metaphor Did to Iran. Middle East Journal, 61(3), 422-440.

Herman, E. S. \& Chomsky, N. (2002). Manufacturing Consent: The political Economy of Mass Media (2nd ed.). New York: Pantheon Books.

Izadi, F. \& Saghaye-Biria, H. (2007). A Discourse Analysis of Elite American Newspaper Editorials: The Case of Iran's Nuclear Program. Journal of Communication Inquiry, 31(2), 140-165. http://dx.doi.org/10.1177/0196859906298073

Keshishian, F. (2004). Acculturation, Communication and the U.S. Mass Media: The Experience of an Iranian Immigrant. In F. E. Jandt (Ed.), Intercultural Communication: A Global Reader (pp. 230- 242). Thousand Oaks, CA: Sage.

Lazar, A. \& Lazar, M. M. (2004). The discourse of the New World Order: 'outcasting' the double face of threat. Discourse \& Society, 15(2-3), 223. http://dx.doi.org/10.1177/0957926504041018

Mafinezam, A. \& Mehrabi, A. (2008). Iran and its Place among Nations. Westport, Conn.: Praeger.

Mughees-uddin, S. (1995). Image of Iran in the Western Media, Iranshenasi Quarterly Journal, XXXVIII (4), $32-48$.

Naficy, H. (1995). Mediating the Other: American Pop Culture Representation of Postrevolutionary Iran. In Kamalipour, Y. R. (Ed.), The U.S. Media and the Middle East: Image and Perception (pp. 73-85). Westport, CT: Praeger.

Peña, C. V. (2002). Axis of Evil: Threat or Chimera? Mediterranean Quarterly, 13(3), 40-57. http://dx.doi.org/10.1215/10474552-13-3-40

Reisigl, M. \& Wodak, R. (2009). The Discourse-Historical Approach (DHA). In R. Wodak, \& M. Meyer (Eds.), Methods of Critical Discourse Analysis (2nd ed.) (pp. 87- 121). London: Sage. 
Reisigl, M., \& Wodak, R. (2001). Discourse and Discrimination: Rhetorics of Racism and Antisemitism. London: Routledge.

Rice, C. (2006). U.S. Faces 'no Greater Challenge' than Iran. ABC News Online. [Online] Available: http://www.abc.net.au/news/ newsitems/200603/s1588235.htm

Richardson, E. R. (2004). (Mis)Representing Islam: The Rasim and Rhetoric of British Broadsheet newspapers (Discourse Approaches to Politics, Society and Culture. USA: John Benjamins.

Salim, F. A. (2010). Exploring U.S. Media Reporting About "Islam" and "Muslims": Measuring Biased or Unbalanced Coverage. Graduate Major Research Papers and Multimedia Projects. Paper 2. [Online] Available: $\mathrm{http} / / /$ digitalcommons.mcmaster.ca/cmst_grad_research/2

Smith, E. J. (1999). Leadlines May Be Better Than Traditional Headlines. Newspaper Research Journal, 20 (1), 55-64.

Tadayon, K. M. (1982). The Changing Image of Iran in the United States: Open- Ended Format Surveys before and after the Hostage Crises. International Communication Gazette, 30, 89-95. http://dx.doi.org/10.1177/001654928203000202

Van Dijk, T. (2001b). Critical Discourse Analysis. In D. Schiffrin, D. Tannen, \& H. E. Hamilton (Eds.), The Handbook of Discourse Analysis (pp. 352-371). Maiden, MA: Blackwell.

Van Dijk, T. A. (1984). Prejudice in Discourse: An Analysis of Ethnic Prejudice on Cognition and Conversation. Philadelphia: J. Benjamins.

Van Dijk, T. A. (1985). Structure of News in the Press. In T. A. Van Dijk (Ed.), Discourse and Communication: New Approaches to the Analysis of Mass Media Discourse and Communication (pp. 69-93). Berlin: Walter de Gruyter. http://dx.doi.org/10.1515/9783110852141.69

Van Dijk, T. A. (1991). Racism and the Press. London: Routledge.

Van Dijk, T. A. (1995). Discourse Semantics and Ideology. Discourse \& Society, 6 (2), 243-289. http://dx.doi.org/10.1177/0957926595006002006

Van Dijk, T. A. (2000b). On the Analysis of Parliamentary Debates on Immigration. In M. Reisigl, \& R. Wodak (Eds.), The Semiotics of Racism: Approaches to Critical Discourse Analysis (pp. 85- 103). Vienna: Passagen Verlag.

Van Dijk, T. A. (2001a). Multidisciplinary CDA: A plea for diversity. In R. Wodak, \& M. Meyer (Eds.), Methods of Critical Discourse Analysis (pp. 95-120). London: Sage. http://dx.doi.org/10.4135/9780857028020.d7

Van Dijk, T. A. (2000a). Ideology and Discourse: A Multidisciplinary Introduction. Pompeu Fabra University, Barcelona. [Online] Available: http://www.discourses.org/UnpublishedArticles/ Ideology\%20and \%20discourse.pdf

Van Dijk, T. A. (2000c). The Reality of Racism. On Analyzing Parliamentary Debates on Immigration. In G. Zurstiege (Hrsg.) Festschrift Für die Wirklichkeit (=Festschrift for Siegfried Schmidt) (pp. 211-226). Wiesbaden: Westdeutscher Verlag.

Van Dijk, T. A. (2002). Review of Discourses of Domination: Racial Bias in the Canadian English-Language Press by Frances Henry and Carol Tator. Canadian Journal of Sociology Online. [Online] Available: http://www.cjsonline.ca/pdf/discdom.pdf (September - October 2002)

Wodak, R. \& Busch, B. (2004). Approaches to Media Texts. In Downing, J. D., McQuail, D., Schlesinger, P., \& Wartella, E. (Eds.), The Sage Handbook of Media Studies (pp.105-122). Thousand Oaks, CA: Sage.

Wodak, R. (2001). The Discourse-historical Approach. In R. Wodak, \& M. Meyer (Eds.), Methods of Critical Discourse Analysis (pp. 63-94). London: Sage. http://dx.doi.org/10.4135/9780857028020.d6

Wodak, R. (2006). Discourse-Analytic and Socio-Linguistic Approaches to the Study of Nation(alism). In G. Delanty, \& K. Kumar (Eds.), The Sage Handbook of Nations and Nationalism (pp. 104-117). London: Sage. 